\title{
Communication Strategy to Develop Local E-Marketplace in Samarinda City
}

\author{
http://dx.doi.org/10.25008/jkiski.v6i1.508
Ainun Nimatu Rohmah ${ }^{1}$, Kadek Dristiana Dwivayani ${ }^{2}$, Kheyene Molekandella Boer ${ }^{3}$ \\ ${ }^{1,2,3}$ Department of Communication Science, Universitas Mulawarman \\ Jl. Muara Muntai Gn. Kelua, Samarinda, 75119 - Indonesia \\ *Corresponding author: ainunrohmah@fisip.unmul.ac.id
}

Submitted: March 04, 2021, Revised: April 10, 2021, Accepted: May 29, 2021

Accredited by Kemristekdikti No. 28/E/KPT/2019

\begin{abstract}
COVID-19 has impacted micro, small, and medium enterprises (MSMEs) business in Indonesia. One of the efforts of MSMEs to survive is by migrating to the digital market. The city government of Samarinda grabs the opportunity by releasing a mobile application called Behambinan. This study examines the Behambinan communication strategy to empower MSMEs, considering the apps as an innovation for the digital market in Samarinda. The Diffusion of Innovation Theory helps to parse the communication strategies of this innovation. The method used in this study is qualitative descriptive by conducting indepth interviews with the Communication and Information Office of Samarinda City and its stakeholders as key actors of the diffusion process. The Behambinan application is currently at the dissemination stage to act effectively as the local digital forum for buying and selling. This study found some challenges during the diffusion process. First, MSME players (adopters) have difficulty understanding the application due to the lack of digital literacy and technical issues such as not having a smartphone and high expense for internet quotas to run the application. Second, the misalignment of interpersonal communication between key actors. Third, weaknesses in promotional strategies. This study found that interpersonal communication through localite channels has a significant role in the diffusion process. An integrated communication strategy among key actors and well-planned execution of localite and cosmopolite channels is essential to engage MSMEs and the public.
\end{abstract}

Keywords: COVID-19; MSMEs; e-marketplace; empowerment; innovation

\section{Introduction}

Smartphones have changed people's daily lives, starting from how people live and communicate to make transactions. The diffusion that occurs due to the use of mobile devices, supported by internet networks and the development of an online business ecosystem broadens the choices for consumers (Täuscher \& Laudien, 2018). The online shopping trend has become a new pattern of behavior for consumers. Supported by technological sophistication in making the process of buying and selling transactions much easier, one of which is through a mobile application. Behavioral changes of mobile application usage among consumer are generally preceded by trailing behavior (Salo \& Makkonen, 2018). However, the customer behavioral changes of using mobile applications are considered simpler than physical products or services because they are only one click away without excessive effort (Bhattacherjee et al., 2012). In other words, mobile application providers face the challenge of taking advantage of the 
opportunity and time during the trial period to retain users (Salo \& Makkonen, 2018).

The COVID-19 pandemic has strengthened changes of consumer behavior since people's mobility to meet their needs is limited. However, according to the Senior Economist of the Institute for Development of Economics and Finance (INDEF), Enny Sri Hartati, MSMEs are the most vulnerable sectors during the pandemic (Irham, 2020). On the one hand, UMKM is a sector that is considered the most capable of surviving a crisis (Suryana, 2019). This is because most MSMEs in Indonesia are micro-businesses in the informal sector that use local raw materials and target local markets (Sudaryanto et al., 2013). On the other hand, only $13 \%$ of 8 million MSME players nationally are connected to the digital ecosystem (Saptowalyono, 2020), while only $9 \%$ of SMEs have adopted the e-marketplace strategy since the launch of the Go Online program by the government in 2017 (Ngazis \& Hasanah, 2019).

During the pandemic, MSMEs experienced a decline in income during the pandemic due to the requirement to minimized face-to-face communication. This impact does not only affect 1,785 cooperatives and 163,713 MSME actors nationally (Kristianus, 2020), but also at the local regional level. The research by the Bank Indonesia Representative of East Kalimantan found that $90.10 \%$ of MSMEs in East Kalimantan experienced a decline in sales during the pandemic and $49.20 \%$ of MSMEs were forced to terminate employment (Ghofar, 2020). In East Kalimantan, there are more than 13,000 MSMEs proposed to receive a stimulus from refocusing the APBD for the pandemic (Disway Kaltim, 2020). Meanwhile, from the marketing side, the government directs MSME players to migrate to online or e-commerce systems, one of which is through applications (Irham, 2020). Therefore, the digitizing activity of MSMEs is a rational option to support MSMEs, even before the pandemic.

Technology becomes one of the important tools to support competitiveness in the digital age of commerce. Adoption of information technology (IT) is one of the areas recommended to the SMEs to face competitive challenges (Nugroho et al., 2017). In developing countries such as Indonesia, the adoption of IT provides solution for affordability, accessibility and quality problems of SMEs (Sani et al., 2020). Moreover, being innovated in technological approach provide competitive advantages for SMEs (Wadhwa et al., 2017). The SMEs contributes to technological innovation in the economy as it is necessary for the SMEs to gain competitive advantage or survive in the globalized market (new market and consumers) (Prasanna et al., 2019). SMEs need to pay attention and be able to gain an advantage from technological opportunities to support business strategies and improve operations and services (Indrawati et al., 2020).

The pandemic has accelerated the shift towards digitalization and e-commerce during the change in customers habit due to lockdowns and social distancing rules (Shrestha, 2020). The Ministry of Communication and Information Technology of Indonesia urges small and medium businesses to go online, especially by joining e-commerce platforms where e-commerce increased SMEs revenue by $26 \%$ and increased workforce (Kementerian Komunikasi dan Informasi Indonesia, 2017). The adoption of e-commerce in the MSME sector in Indonesia is still low although it is proven to provide benefits such as expanding market reach, increase sales and improve external communication (R. Rahayu \& Day, 2017).

However, ICT adoption of SMEs in Indonesia has not reached the strategic level of its business. Raharja et al. (2019) recommended training for business people and socialising the benefits of ICT adoption of SMEs are important to encourage ICT adoption in Indonesia. It is due to the limitation of human resource and knowledge of IT utilization and benefits for SMEs' business (Nugroho et al., 2017). Competitive pressure becomes one of the challenges for SMEs in adopting e-marketplace in Indonesia (Purwandari et al., 2019). Another research from Indrawati et al. (2020) extrapolated the biggest inhibiting factor of technological innovation for SMEs in Indonesia is the funding of technological innovation and support from government institutions.

The government of Samarinda city in East Kalimantan Province Indonesia have taken chance of approaching the digital environment. In 2019, they launched a mobile application named Behambinan as a local e-marketplace targeting SMEs. A marketplace can be defined as the place for buyers and sellers to meet, talk about the product, and finally perform transactions (Prihastomo et al., 2018). Ideally, purchasing activities also happens through the application. Due to some technical limitation, Behambinan has not provided the activity yet. Aside from the technical development, the 
application itself can be considered as an innovation for local SMEs empowerment, either for the SMEs or for customers.

\section{Theoretical Framework}

Innovation is defined as an idea, practice, or object that is perceived as new by an individual or other unit of adoption (Singer, n.d.). For SMEs and the community, the local emarketplace mobile application is an innovation for local products. Local market reach can be a competitive advantage that both providers and SMEs must maximize to reach a specific market. The challenge comes not only in preparing for SMEs to compete in the online market. However, in terms of mobile applications, Behambinan also has to compete with mobile application competitors who have advanced technical capabilities with a broad market. This process is known as the diffusion of innovation, which is the process that occurs when people adopt new ideas, practices, principles or products (Kaminski, 2012)

The idea of diffusion of innovation is defined as the social process to learning about an innovation affected by set of pros and cons of the innovation, the characteristics of adopters, and larger social and political context (Dearing \& Cox, 2018). Rogers in his notable work the Diffusion of Innovation (DOI) Theory argue that communication channels, interpersonal networks and social modelling were particularly influential aspects in the change process (Scott \& McGuire, 2017). The theory is widely used to explained phenomenon in organization, business and communication. One of which is Banks (2006) who found an interrelated linkage between and successful strategy of change management of innovation. She noted that internal stakeholders' literacy of innovation and the ability to communicate, collaborate and gain support of management are essentials to a successful strategic change management (Banks, 2006).

According to Rogers (2003), innovation will go through five stages in the adoption process, namely: Knowledge, Persuasion, Decision, Implementation, and Confirmation. At the knowledge stage, an individual learns about the existence of innovation and seeks information about the innovation. At this stage, the individual will ask three types of knowledge, namely: awareness-knowledge related to knowledge about the existence of innovation, how-to-knowledge related to information about how to use innovation correctly, and principles-knowledge related to functional principles about how and why an innovation works (Rogers, 2003b). At the persuasion stage, potential adopters will be more involved than the knowledge stage and begin to actively seek information. Individuals will create positive and negative attitudes towards innovation and develop innovative perceptions so that the character of innovation will be formed (Rogers, 2003b).

The persuasion stage occurs when the individual has formed a behavior after understanding the knowledge of innovation, both positive and negative. At this stage, the affective approach (feelings) is more influential, one of which is an assessment of colleagues (Rogers, 2003b). At the decision stage, the individual will choose to adopt or reject the innovation. Rogers shows two types of rejection, namely active rejection, and passive rejection. On active resistance, the individual tries an innovation and thinks about adopting it, but it is not done. Meanwhile, in the passive refusal, the individual did not think to adopt the innovation at all. At the implementation stage, the innovation has been adopted by individuals. However, this stage brought new uncertainties regarding the outcome of the diffusion that occurred. It is at this stage that upgrading, and modification of innovation are carried out to maintain adopters (Rogers, 2003b). Finally, at the confirmation stage, the innovation-decision has been made but the individual will see support for his decision to adopt the innovation.

\section{Communication Channels}

The communication process occurs at each of these stages through various communication channels to achieve mutual understanding from the participants. Communication channels can be categorized into localite channels and cosmopolite channels. Mass media is a cosmopolite channel that is more significant at the knowledge stage while localite channels such as interpersonal channels are very important in the persuasion stage for the innovation-decision process (Rogers, 2003a). Apart from the innovation process and communication channels, other important elements in the diffusion of innovation are time and social systems.

The entire innovation process involves a time dimension that occurs in a social system so that it is influenced by the social structure and the agreement patterns of the units in the system (Rogers, 2003a). The main obstacle in the process of adopting innovation is the existence 
of uncertainty, namely the consequence of a change in the form of rejection of individuals or the social system. To reduce uncertainty, individuals must be informed about the advantages and disadvantages that make them aware of all consequences (Rogers, 2015).

\section{Communication Strategy}

The strategic orientation in the organization greatly influences the diffusion of innovation. Organizations that combine a customer-technology orientation tend to go beyond organizations that only focus on one of them (Adams et al., 2019). One of them is a form of communication strategy. Communication strategy is a pattern in important decisions and actions related to communication and determines what must be communicated to avoid conflict and reach mutually beneficial solutions in relationships with stakeholders (Heath et al., 2018). At functional level organization's strategic goals and priorities are delivered through its communication themes as part of deliberate communication strategy process and at operational level implemented in the communication planning process (Heath et al., 2018). Meanwhile, the process of adopting ICT by SMEs requires some key capabilities. The capabilities required include problem assessment, conceptualizing and evaluation, specifying concepts, delegating roles, identifying appropriate and inappropriate interests, testing products, modifying and adapting products, and redefining problems (Sunday \& Vera, 2018). Those capabilities must be induced well alongside with the communication strategy.

Ebadi \& Utterback (1984) found a close relationship between the role of communication and technological innovation in which the greater the effect of centrality and diversity in technological innovation. Following Ebadi \& Utterback study, Che et al. (2019) found that the successful diffusion of ideas in an organization is strongly supported by literacy and transparent communication between individuals in the organization. Meanwhile, Kamboj \& Rahman (2017) found that innovation is associated with technical processes related to marketing capabilities and non-technical processes that are simultaneously related to competitive advantage. Furthermore, they underlined that the role of managers in managing communication strategies with internal and external stakeholders is an important component in the success of introducing new products and competing with competitors (Kamboj \& Rahman, 2017).

Based on the study of various literatures, this study assumes that communication strategies impact the success of introducing local e-marketplaces as a marketing innovation in the pandemic era. Therefore, this study seeks to analyse the communication strategies applied by providers in promoting Behambinan as well as the diffusion of innovation that occurs in the process.

\section{Material and Methodology}

This research uses a qualitative approach. In qualitative research, the main instrument is the person or the researcher himself who must have broad insight from concepts and theories to ask, analyze and then construct the meaning of the situation under study (Sugiyono, 2017). Lofland in Moleong (2014) explains that the sources of qualitative research data are words and actions. There are two sources of data, namely primary data and secondary data. Primary data is obtained directly from research subjects according to the specified instruments, while secondary data is in the form of evidence, notes, or reports that have been published to assist analysis in research (Purhantara, 2010). This method uses a qualitative approach with the snowball sampling method of informant retrieval. The informant will initially provide recommendations for other informants to be interviewed in-depth. Researchers have determined two initial informants in this study. The first key informant is Head of Government Applications and Services the Communication and Information Office and Samarinda City, Mr. Suparmin. The second key informant is Cooperative and UMKM Office, Mrs. Mariah. Then proceed to the Population Control and Family Planning Office of Samarinda City as a stakeholder, MSME actors as sellers, as well as to buyers (users) of the Behambinan application.

\section{Result and Discussion}

Advances in information technology change the pattern of transactions and business developments in the world. The use of the internet also supports the existence of micro, small and medium enterprises in various aspects of business, from marketing, transactions to long-term consumer loyalty. The ease and speed that an internet-based application offers, brings innovation to SMEs in the city of Samarinda. 'Moving' traditional markets into an online marketplace (marketplace), which is 
downloaded on the smartphone of every consumer who needs it. Especially during the Covid 19 pandemic, there were restrictions imposed according to health protocols. An example of information technology innovation is the creation of the Behambinan application in the city of Samarinda.

This application was originally intended to facilitate consumers who will break their fast during Ramadan, without leaving the house and avoiding crowds. A number of food and beverage products are offered through the Behambinan application. The use of the Behambinan marketplace application is a new experience for MSME players and the community. This application was originally intended as an alternative media for buying and selling the Ramadan market which must be closed during the pandemic. Usually, people will come to the market or Ramadan bazaar in various locations that have been provided.

Behambinan is the result of the adoption of the Gendong Gandeng Program, which is an MSME empowerment program from the Yogyakarta City Government that aims to alleviate poverty. This program was launched in 2018 and also has a local marketplace application called Nglarisi. Unfortunately, the Nglarisi application has not been able to optimally support MSME businesses digitally due to technical problems, the ability of Gendong Cooperate members to use the application is still lacking, and the lack of demand (Subarkah, 2019).

This study sees Behambinan as a useful local marketing innovation for SMEs. In general, MSMEs register themselves in emarketplaces with large markets, such as Tokopedia or Bukalapak, which provide a digital market for buying and selling transactions. Unfortunately, based on the results of a survey by the Indonesian Internet Service Providers Association (APJII), the most traded commodity in the national marketplace is durable products, considering that this marketplace promises a national and global market and tighter business competition (APJII, 2019). Non-durable products, such as certain foods, will be constrained by location and delivery time factors. Therefore, this marketplace is not suitable for the type of micro business with a local market base.

The high uncertainty that occurs in the digital ecosystem forces the firm's ability to prepare strategic decisions in predictive rationality (Koch \& Windsperger, 2017). This occurs in the process of diffusion of
Behambinan's innovation. Most of the MSME players who were members of Behambinan in the early stages were business actors with a nondurable products business base. For example, SMEs who joined the Office of Population Control and Family Planning. Of the 121 registered SMEs, 39 were registered in the Behambinan app. This uncertainty is due to technical limitations (i.e. not having a smartphone, limited capital) and understanding of online marketing that MSMEs players have.

The process of empowering SMEs through the Behambinan application has been carried out by providers in collaboration with related stakeholders. One of them is shown by the presence of 19 groups of assisted SMEs who are partners with the Samarinda City Government. City Government Partners are groups of SMEs that work with the government to provide food and drinks for City Government activities and later on for all agencies in the Samarinda City Government. Unfortunately, MSME actors also encounter problems in becoming partners because they have to meet certain criteria, including having a business license that meets the standards of the City Government, having sufficient capital, entrepreneurs providing food and drink, being able to fulfill orders without using the cash on delivery method. In addition, stakeholders observed that the common obstacle of the Behambinan application is related to the promotion where this application is not widely known by the public so that orders are limited or even absent in a day. Behambinan must be able to compete with other mobile application competitors to become the choice that customers have in mind.

\section{Communication Process in the Diffusion Innovation}

The communication process occurs in every stage of the diffusion of innovation, both through localite channels and cosmopolite channels. As an application initiated, created, and managed by the regional apparatus, namely the Samarinda City Information and Communication Office, Behambinan was introduced as the government-owned innovation to empower SMEs. This introduction process made use of influential figures in the Samarinda city government, such as the Mayor. These figures consistently convey information as well as invitations to use Behambinan, starting with employees within the City Government itself. This consistency is followed up by local regulations that support the use of Behambinan. Another form of localite 
channel comes from external stakeholders who are involved in coaching SMEs.

Interpersonal channels are stronger for creating or changing individual behavior (Sahin, 2006). Though, this study found the different consistency of interpersonal communication between the two stakeholders. At the Population Control and Family Planning Service, the interpersonal communication process is a key point to increase knowledge and interest and eliminate the uncertainty of SMEs players in using Behambinan. Interpersonal communication is carried out by SME coaches through various media, both faceto-face, and online coaching through communication applications. Unfortunately, stakeholders from the Department of Cooperatives \& SMEs Samarinda City did not do the same. These stakeholders tend to be neutral and are reluctant to prioritize Behambinan as the main application for the SMEs they develop, on the grounds that competitors provide more profitable opportunities for SMEs.

Meanwhile, the provider and manager of Behambinan, namely the Communication and Information Office, focuses on communication through the cosmopolite channel. The first step is to create a unique communication concept to be conveyed through the application. For example, by making jokes or interesting phrases to greet users of the Behambinan application every day. Providers also carry out online and offline promotions by utilizing communication media within the Samarinda City Government and the mass media. The provider also arranges events and programs to introduce Behambinan, especially targeting young people as active smartphone users.

In addition, providers also communicate through localite channels by forming SMEs communication groups on WhatsApp, in addition to being willing to conduct direct consultations with SMEs. This was revealed by one of the SME business actors who are users of Behambinan, Mrs. Herlina. He appreciates providers who are open to receiving complaints and questions from him at any time, even when he comes directly to the Office of Communication and Information. The communication approach taken by the Samarinda City Communication and Information Agency to Mrs. Herlina has used persuasion and affection so that there is mutual trust.

This study notes that the Samarinda City Communication and Informatics Office does not yet have a regular training program to gain the trust of SMEs in general. Training programs do not merely provide information, but to create knowledge education and training must provide a know-why experience rather than just how-to experience (Seemann, 2003). Providers and stakeholders as well as other actors involved in the diffusion of innovation in empowering SMEs must focus their attention on the interests and arrangements of SMEs to ensure that goals are connected to the views and mindsets of the actors (Sunday \& Vera, 2018).

Another problem encountered is the lack of technological knowledge of the SME actors. Many of the SME players who are members of the empowerment group run by the Samarinda city government refuse to try Behambinan because they do not understand e-commerce, do not own smartphones, or are worried about internet quota costs. Consumers can reject innovation due to a lack of awareness of the investment if they feel the innovation is not right for them (Salim, 2019). One strategy to increase awareness of innovation is through a professional community that can create and transfer knowledge to bring change (BenSlimane et al., 2020; Sapir et al., 2016). The process of communication innovation by professionals to specific groups can be done through personal cosmopolite channel activities such as community visits, campaigns, training, or exhibitions (Sharma \& Kumar, 2018).

\section{Communication Strategy to Develop Local E- Marketplace as an Innovation}

The manager of the Behambinan mobile application is the Samarinda City Information and Communication Office. The office appointed a small team of four to carry out roles of managing Behambinan from technical development to customer service who connecting buyers and sellers. This team is the organization of the Behambinan application as part of the information and communication technology ecosystem in the city of Samarinda. As part of the Samarinda city government, this team is not focused on running the Behambinan application as a business unit. The actors who run this application management are employees who are tied to other main tasks and functions according to the work unit in the Samarinda city government. Therefore, the team faces some challenges in managing Behambinan under the pressure from city leaders to bring this mobile application of SMEs empowerment into success. On the one hand, this condition facilitates coordination with internal 
stakeholders who are supported by various policies to achieve goals. On the other hand, this team has limitations of resources in developing applications to compete with competitors.

The communication strategy makes the communication function in the management process relevant according to its focus and involves the right stakeholders so that communication becomes a solution to organizational problems (Heath et al., 2018). The formulation of a communication strategy, both functional and practical, was carried out by the Behambinan team in coordination with the leaders of the Communication and Information Office and the Mayor of Samarinda. This team does not have a professional communication practitioner in the organization to implementing a strategy for developing organizational or business communication strategies. Professional communication practitioner is an essential element for creating an organization and determine strategic issues (Heath et al., 2018).

Consumers are active users. The seller offers sales until the goods reach the consumer. Meanwhile, buyers can buy, to review the product. In addition, consumer reviews can provide ratings, share again (share), or recommend a product again to various social media. This condition also changes the character and patterns of consumer spending. In e-commerce, effective marketing communication carried out from an integrated coordination between organization's functions and strategies (Kliatchko, 2013).

Rahayu \& Fatima (2019) in their research about big e-commerce firm Lazada examined some marketing communication strategies used are advertising (via electronic media, printed media and social media), sales promotion on the website, promo code, word of mouth, and utilizing social media. This research found that local e-marketplace Behambinan has not utilize an integrated marketing communication as such big firm did. Behambinan does not has a company website under its brand name, instead they manage information mainly through social media Instagram. The content of Behambinan's Instagram account mostly random thoughts, motivational quotes, tips, and certain festive speeches. Tough the designs are interesting enough, but only small portion of information talk about SMEs products and promotional deals or events.

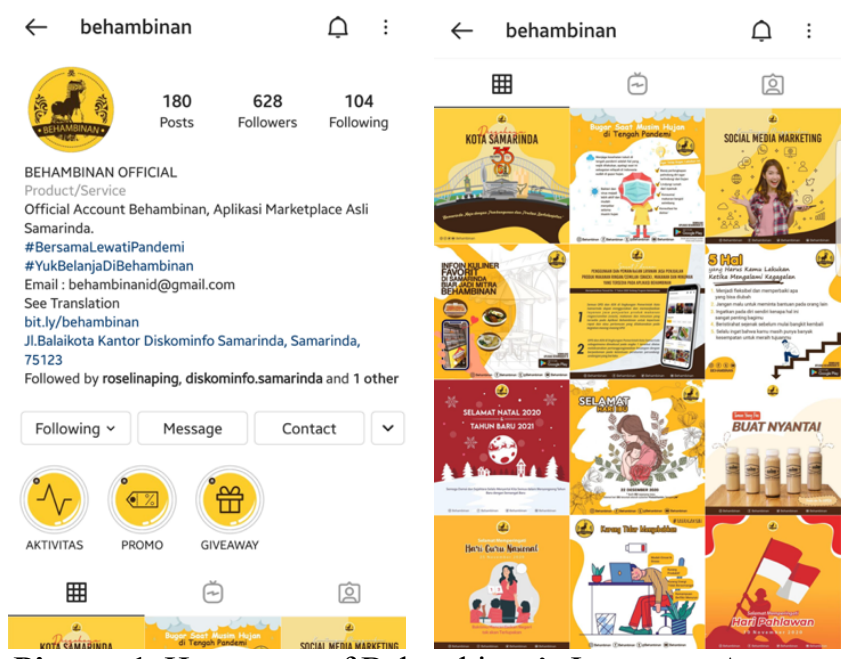

Picture 1. Homepage of Behambinan's Instagram Account

To sum up, this study examined strategies carried out in this innovation process, from diffusion (dissemination of innovation information) to empowering MSMEs that can develop sustainably. According to Rogers, there are five stages in the innovation acceptance process, namely the knowledge stage, the persuasion stage, the decision stage, the implementation stage, and the confirmation stage (Damastuti, 2020).

First, at the strategic knowledge stage carried out by the Samarinda City Communication and Information Agency is the
Introduction to Internal and External Behambinan Applications. Where the tactics are carried out, namely the socialization of the Behambinan application at the internal level (employees) at the Regional Apparatus Organization (OPD) of Samarinda City, such as the population office, cooperative and SMEs offices, and others. Meanwhile, the external introduction is to all people of Samarinda city, through local mass media. Second, in the persuasion stage, the strategy is carried out by providing excellent service to consumers (users) and sellers (sellers). Third, the strategy 
decision stage determines the continuity of the application. The Behambinan application is accepted or rejected by the target. The point is that both users and sellers are given more benefits from using this application. For example, educational messages and motivation for users and sellers.

The fifth is the implementation stage (implementation) of the coaching strategy to the sellers (SMEs). Where the Ministry of Communication and Information provides training in business development. The last step is confirmation. Looking for reinforcement of decisions that have been taken. In this stage, it proves useful innovation itself (Haryanto, 2007). The strategy at the confirmation stage is effective communication and consistency.

Table 1. Communication Strategies in DOI Stages of Behambinan Applications

\begin{tabular}{|c|c|c|c|}
\hline Number & $\begin{array}{c}\text { Diffusion of Innovation } \\
\text { Stages }\end{array}$ & $\begin{array}{l}\text { Communication } \\
\text { Strategy }\end{array}$ & Tactics \\
\hline 1 & Knowledge & $\begin{array}{l}\text { Internal and External } \\
\text { Introduction of } \\
\text { Behambinan } \\
\text { Applications }\end{array}$ & $\begin{array}{l}\text { Internal: } \\
\text { Socialization to regional } \\
\text { apparatus organizations in } \\
\text { Samarinda city } \\
\text { External: } \\
\text { Socialization to the people of } \\
\text { Samarinda city through mass } \\
\text { media }\end{array}$ \\
\hline 2 & Persuasion & $\begin{array}{l}\text { Excellent service to } \\
\text { users and sellers }\end{array}$ & $\begin{array}{l}\text { The application is easy to } \\
\text { download and use, promotes } \\
\text { delivery costs (courier), } \\
\text { provides a large selection of } \\
\text { food and beverage products, } \\
\text { accessories, and more } \\
\text { Opening the opportunity to } \\
\text { accept potential sellers }\end{array}$ \\
\hline 3 & Decision & $\begin{array}{l}\text { Benefits for both sellers } \\
\text { and users }\end{array}$ & $\begin{array}{l}\text { Providing more benefits } \\
\text { through educational messages } \\
\text { applied, for example, health } \\
\text { protocol info, tips, and } \\
\text { motivation to build a business } \\
\text { and others. }\end{array}$ \\
\hline 4 & Implementation & MSMEs empowerment & $\begin{array}{l}\text { Establish cooperation } \\
\text { (partners) with other agencies } \\
\text { related to MSME development. } \\
\text { Guide training to increase } \\
\text { MSMEs to sellers }\end{array}$ \\
\hline 5 & Confirmation & $\begin{array}{c}\text { Effective } \\
\text { communication and } \\
\text { consistency }\end{array}$ & $\begin{array}{l}\text { Provide admin contact } \\
\text { information for questions, } \\
\text { criticisms, and suggestions. } \\
\text { Create a WhatsApp or telegram } \\
\text { group specifically for the seller } \\
\text { of the Behambinan application }\end{array}$ \\
\hline
\end{tabular}

\section{Conclusions}

Based on the analysis above, it can be concluded that there are five strategies to develop a local e-marketplace as SMEs empowerment innovation, namely: Introduction to Internal and External Behambinan Applications, Excellent Service to users and sellers, Benefits for sellers and users, MSME's Development, Effective Communication, and consistency. Internal introductions are made to internal stakeholders, including MSMEs who are part of this application. Internal recognition was carried out using localite channels and cosmopolite channels as an innovation diffusion communication strategy. Meanwhile, the related external introduction focuses on reaching the widest possible market. This is done in particular by utilizing cosmopolite channels both through the city governmentowned communication channels and the mass media.

The decision to adopt a local emarketplace mobile application by MSMEs is influenced by the communication process 
through localite channels and cosmopolite channels. The results of this study support previous research (i.e. Vrain \& Wilson, 2021) which found that interpersonal channels have a significant role in the diffusion process of innovation. The results of this study also confirm that the decision to adopt an innovation is an interactive and dynamic process of actors connected to MSMEs (both internal providers and external stakeholders) (Sunday \& Vera, 2018). Thus, consistency of information and support for local applications must be carried out by key actors, especially external stakeholders who have direct contact with MSMEs. As the results are shown by Sharma \& Kumar (2018), a personal cosmopolite channel in the form of training and enrichment activities is an efficient source of communication for potential adopters.

This study found that the communication channel has not been maximized in an integrated manner with various stakeholders which is the cause of misalignment of understanding between actors. From the customer side, communication through cosmopolite channels is needed to introduce the Behambinan application to the target market. The results of this study found that the use of cosmopolite channels is still limited to channels owned by the government and partners who have long collaborated with providers. Providers can expand promotions by utilizing social networking well and local influencers to share reviews to attract potential customers' curiosity.

Behambinan is an e-marketplace mobile application that is currently in the dissemination stage. At this stage, knowledge and awareness of the importance of this innovation are needed to reach potential adopters. The results of this study suggest the Behambinan team uses appropriate communication strategies with the right channels to introduce Behambinan respectively to MSMEs and the public.

\section{Acknowledgements}

This research was carried out with funding sources from the Faculty of Social and Political Sciences, Mulawarman University in 2020.

\section{References}

Adams, P., Bodas Freitas, I. M., \& Fontana, R. (2019). Strategic orientation, innovation performance and the moderating influence of marketing management. Journal of Business Research, 97, 129140.https://doi.org/10.1016/j.jbusres.2018
.12 .071

APJII. (2019). Penetrasi \& Profil Perilaku Pengguna Internet Indonesia Tahun 2018. In Asosiasi Penyelenggara Jasa Internet Indonesia (APJII). www.apjii.or.id

Banks, C. H. (2006). Diffusion of innovation: communicating to improve training and employee development. International Journal of Strategic Change Management, 1(2), https://doi.org/10.1504/ijscm.2006.01110 8

Ben-Slimane, K., Diridollou, C., \& Hamadache, K. (2020). The legitimation strategies of early stage disruptive innovation. Technological Forecasting and Social Change, 158, https://doi.org/10.1016/j.techfore.2020.12 0161

Bhattacherjee, A., Limayem, M., \& Cheung, C. M. (2012). User switching of information technology: A theoretical synthesis and empirical test. Information \& Management, 49(7-8), 327-333.

Che, T., Wu, Z., Wang, Y., \& Yang, R. (2019). Impacts of knowledge sourcing on employee innovation: the moderating effect of information transparency. Journal of Knowledge Management, 23(2), 221-239. https://doi.org/10.1108/JKM11-2017-0554

Damastuti, R. (2020). Adopsi Inovasi Media Komunikasi Pemasaran UMKM Batik Jumputan Di Era Digitalisasi. Jurnal Source Ilmu Komunikasi, 6(2), 164.

Dearing, J. W., \& Cox, J. G. (2018). Diffusion of innovations theory, principles, and practice. Health Affairs, 37(2), 183-190. https://doi.org/10.1377/hlthaff.2017.1104

Disway Kaltim. (2020). 13 Ribu UMKM di Kaltim Dapat Stimulus, Begini Skemanya. Disway Kaltim. https://diswaykaltim.com/2020/04/23/13ribu-umkm-di-kaltim-dapat-stimulusbegini-skemanya/

Ebadi, Y. M., \& Utterback, J. M. (1984). The Effects of Communication on Technological Innovation. Management Science, 30(5), 572-585. https://doi.org/10.1287/mnsc.30.5.572

Ghofar, M. (2020). Survei BI: 90,10 persen UMKM Kaltim Mengalami Penurunan Penjualan. Antara Kaltim. https://kaltim.antaranews.com/berita/7514 0/survei-bi-9010-persen-umkm-kaltimmengalami-penurunan-penjualan

Haryanto, D. P. (2007). Inovasi Pembelajaran. 
Jurnal Perpesktif Ilmu Pendidikan, 6(8), 104.

Heath, R. L., Johansen, W., \& Steyn, B. (2018). Communication Strategy. The International Encyclopedia of Strategic Communication, 1-12. https://doi.org/10.1002/9781119010722.ie sc0036

Indrawati, H., Caska, H., \& Suarman, H. (2020). Barriers to technological innovations of SMEs: how to solve them? International Journal of Innovation Science, 12(5), 545-564. https://doi.org/10.1108/IJIS-04-20200049

Irham, M. (2020). Virus corona: UMKM Diterjang Pandemi Covid-19 Sampai "Kembang Kempis." BBC News Indonesia.

https://www.bbc.com/indonesia/indonesia $-51946817$

Kamboj, S., \& Rahman, Z. (2017). Market orientation, marketing capabilities and sustainable innovation: The mediating role of sustainable consumption and competitive advantage. Management Research Review, 40(6), 698-724. https://doi.org/10.1108/MRR-09-20140225

Kaminski, J. (2012). Theory in Nursing Informatics Column. Canadian Journal of Nursing Informatics, 6(2), 1-7.

Kementerian Komunikasi dan Informasi Indonesia. (2017). Go Digital! Gerakan Nasional UMKM Go Online. Siaran Pers No. 216/HM/Kominfo/11/2017.

Kliatchko, J. G. (2013). The primacy of the consumer in IMC: Espousing a personalist view and ethical implications. The Evolution of Integrated Marketing Communications, Routledge.

Koch, T., \& Windsperger, J. (2017). Seeing through the network: Competitive advantage in the digital economy. Journal of Oragnization Design, 6(6), 1-30.

Kristianus, A. (2020). Teten Masduki : 163 Ribu UMKM Terdampak Covid 19. Investor Daily Indonesia.

Moleong, L. J. (2014). Metodologi Penelitian Kualitatif Edisi Revisi. Bandung: Remaja Rosdakarya.

Ngazis, A. N., \& Hasanah, M. (2019). Baru 9 Persen UKM Go Online, Kominfo Merasa Miris. Viva.Co.Id.

Nugroho, M. A., Susilo, A. Z., Fajar, M. A., \& Rahmawati, D. (2017). Exploratory Study of SMEs Technology Adoption Readiness
Factors. Procedia Computer Science, 124, 329-336.

https://doi.org/10.1016/j.procs.2017.12.16 2

Prasanna, R., Jayasundara, J., Gamage, S. K. N., Ekanayake, E., Rajapakshe, P., \& Abeyrathne, G. (2019). Sustainability of SMEs in the Competition: A Systemic Review on Technological Challenges and SME Performance. Journal of Open Innovation: Technology, Market and Complexity, 5, 1-18.

Prihastomo, Y., Meyliana, Hidayanto, A. N., \& Prabowo, H. (2018). The Key Success Factors in E-Marketplace Implementation: A Systematic Literature Review. Proceedings of 2018 International Conference on Information Management and Technology, ICIMTech 2018, September, 443-448. https://doi.org/10.1109/ICIMTech.2018.8 528189

Purhantara, W. (2010). Metode Penelitian Kualitatif Untuk Bisnis. Graha Ilmu.

Purwandari, B., Otmen, B., \& Kumaralalita, L. (2019). Adoption factors of e-marketplace and instagram for micro, small, and medium enterprises (MSMEs) in Indonesia. ACM International Conference Proceeding Series, 111-116. https://doi.org/10.1145/3352411.3352453

Raharja, S. J., Pratami, W. T., \& Rivani, R. (2019). Adoption of ICT on enhancing business performance: Study on creative industries SMEs in Bangung City, Indonesia. Review of Integrative Business \& Research, 8(2), 20-30.

Rahayu, R., \& Day, J. (2017). E-commerce adoption by SMEs in developing countries: evidence from Indonesia. Eurasian Business Review, 7, 25-41.

Rahayu, S. K., \& Fatima, F. N. (2019). Marketing Communication Strategy with E-Commerce. IOP Conference Series: Materials Science and Engineering, 662(3). https://doi.org/10.1088/1757899X/662/3/032058

Rogers, E. M. (2003a). Diffusion of Innovation Terjemahan Abdillah Hannafi. Usaha Nasional.

Rogers, E. M. (2003b). Diffusion of Innovations, Fifth Edition. In Social Networks.

Rogers, E. M. (2015). Evolution: Diffusion of Innovations. In International Encyclopedia of the Social \& Behavioral Sciences: Second Edition. 
https://doi.org/10.1016/B978-0-08097086-8.81064-8

Sahin, I. (2006). Detailed Review of Rogers' Diffusion of Innovations Theory and Educational Technology-Related Studies Based on Rogers' Theory. The Turkish Online Journal of Educational Technology TOJET, 5(2), 14-23.

Salim, B. T. (2019). Customer Resistance To Innovation Acceptance. Редакиионная Коллегия, 79.

Salo, M., \& Makkonen, M. (2018). Why do users switch mobile applications? Trialing behavior as a predecessor of switching behavior. Communications of the Association for Information Systems, 42(1), $\quad 386-407$. https://doi.org/10.17705/1CAIS.04214

Sani, A., Budiyantara, A., Haryanto, T., Wiliani, N., Manaf, K., \& Firmansyah, E. (2020). Influences of the Environmental Context on the Acceptance and Adoption Technology among SMEs in Indonesia Esa Firmansyah Sekolah Tinggi Manajemen Informatika dan Komputer (STMIK) Sumedang Influences of the Environmental Context on the Acceptance and Adopt. TEST: Engineering and Management, 83(June).

Sapir, A., Drori, I., \& Ellis, S. (2016). The Practices of Knowledge Creation: Collaboration Between Peripheral and Core Occupational Communities. European Management Review, 13(1), 1936.

Saptowalyono, C. A. (2020). Pandemi Percepat Transformasi Digital UMKM. Kompas. https://kompas.id/baca/ekonomi/2020/05/ 15/webinar-umkm-pandemi-percepattransformasi-digital/

Scott, S., \& McGuire, J. (2017). Using Diffusion of Innovation Theory to Promote Universally Designed College Instruction. International Journal of Teaching and Learning in Higher Education, 29(1), 119128.

Seemann, K. (2003). Basic principles in holistic technology education. Journal of Technology Education, 14(2), 28-39.

Sharma, V. K., \& Kumar, R. (2018). Short Communication Communication Sources
Used By the Small Farmers in Adoption of Wheat Technology. TECHNOFAME: A Journal of Multidiciplinary Advance Research, 7(1), 144-146.

Shrestha, R. (2020). SMEs need right skills to shine in e-commerce. The Jakarta Post.

Singer, L. (n.d.). On the Diffusion of Innovations: How New Ideas Spread. Leif.Me. Retrieved January 28, 2021, from https://leif.me/on-the-diffusion-ofinnovations-how-new-ideas-spread/

Sudaryanto, Ragimun, \& Wijayanti, R. R. (2013). Strategi Pemberdayaan UMKM Menghadapi Pasar Bebas Asean. Kementerian Keuangan Republik Indonesia.

https://www.kemenkeu.go.id/sites/default/ files/strategi pemberdayaan umkm.pdf

Sugiyono. (2017). Metode Penelitian Kuantitatif, Kualitatif, dan R\&D. Jakarta: Alfabeta, CV.

Sunday, C. E., \& Vera, C. C.-E. (2018). Examining information and communication technology (ICT) adoption in SMEs. Journal of Enterprise Information Management, 31(2), 338-356. https://doi.org/10.1108/jeim-12-20140125

Suryana, A. (2019). Budaya Organisasi Pada Usaha Kecil dan Menengah (UKM) di Perkotaan dan Perdesaan. The Future of Organizational Communication In The Industrial Era 4.0 (p. 203). Aksel Media Akselerasi.

Täuscher, K., \& Laudien, S. M. (2018). Understanding platform business models: A mixed methods study of marketplaces. European Management Journal, 36(3), 319-329. https://doi.org/10.1016/j.emj.2017.06.005

Vrain, E., \& Wilson, C. (2021). Social networks and communication behaviour underlying smart home adoption in the UK. Environmental Innovation and Societal Transitions, $\quad 38, \quad 82-97$. https://doi.org/10.1016/j.eist.2020.11.003

Wadhwa, P., McCormick, M., \& Musteen, M. (2017). Technological innovation among internationality active SMEs in the Czech economy: Role of human and social capital of CEO. European Business Review, 29(2). 